\title{
Development of Physics Teaching Media Using Speed Sensors as Speed Analysis in Realtime Based on Arduino to Remind Students' Problem Solving Abilities
}

\author{
Umi Pratiwi ${ }^{1}$, Siska Desy Fatmaryanti ${ }^{2}$ \\ Universitas Muhammadiyah Purworejo, Indonesia ${ }^{1,2}$ \\ umipratiwi@umpwr.ac.id ${ }^{1}$, siskadesy@umpwr.ac.id ${ }^{2}$
}

Received: June $15^{\text {th }}, 2020$. Revised: August $2^{\text {nd }}, 2020$. Accepted: August $10^{\text {th }}, 2020$

\author{
Keywords : \\ Teaching Media; Speed \\ Sensor; Problem Solving
}

\begin{abstract}
Learning about motion material such as straight-motion changes irregularly requires learning aids to analyze more deeply about speed. The problem that often occurs in learning motion material is that this material is only conveyed in the form of theory, has not touched the psychomotor domain from theory to practice. The concept of initial velocity and final velocity on the Irregularly Changing Straight Motion concept will be challenging to understand when dealing with applicable problems. Therefore we need learning aids to understand more integrally between theory and practice in analyzing speed by using a speed sensor (speed sensor). The speed sensor is used as an analysis of the real rate or travel time of Arduino-based objects. This study aims to develop physics teaching media using speed sensors as a realtime analysis based on Arduino. This research is a research \& development $(R \& D)$ research using the Addie development model. The development stage of teaching aids consists of four stages, namely the analysis phase to analyze the needs of students and the components needed based on needs analysis, the design stage as a design stage based on needs analysis, the development stage is the stage of validating tools that have been designed by Ahlia Media and designing based on input by media experts..The results showed that the developed media produced expert validation values or the feasibility of the media with a category suitable for use in learning. The trial results show the learning media can increase the ability of problem solving by $2.2 \%$.
\end{abstract}

\section{INTRODUCTION}

Physics as a part of science is very important in the development of science and technology [1]. Physics has been introduced from elementary school to university, but there are many obstacles faced in learning physics. In addition to the difficulty factor of students in understanding physical concepts, it also 
becomes quite an obstacle about other facilities such as laboratory facilities [2]. Physics as a natural science that studies various natural phenomena that occur around the learning environment is imperative not only to learn concepts or theories in the classroom, but it requires supporting facilities that are no less important than the basic facilities namely laboratory facilities [3]. Practical learning will make students better understand and be in direct contact with natural phenomena that occur. Practical learning will create meaningful learning, meaning students can apply or apply their knowledge in everyday life [4].

Students have low ability to understand abstract concepts which are quite crucial obstacles [5]. One way to develop student knowledge gained in the classroom is by developing learning media. Learning media developed as a learning tool for students to better understand concepts accepted in the classroom and can be practiced in laboratory learning [6]. Students who are less interested in physics can be overcome by applying interesting learning media. Media are able to build active interaction between students and teachers and facilitate the process of knowledge transfer [7]. Appropriate learning media for physics material is one of practicum media which has the characteristics of the material or concept being studied [8].

Technology-based learning media such as using a microcontroller is a media that is widely used today, in addition to being digita also has a level of precision that is better than conventional media [9]. Microcontroller is a micro-scale computer system that is commonly used for a controller or controller system and is programmed according to the needs and objectives of the tool made [10]. The microcontroller used is Arduino which is an electronic circuit that is open source and has hardware and software that is easy to interact. Arduino can recognize the surrounding environment by integrating with various types of sensors and can control lights, motors, and various other types of actuators. Arduino has many types, including Arduino Uno, Arduino Mega 2560, Arduino Fio, and others [11].

The teaching media uses a microcontroller with various advantages being a solution for developing teaching media on the motion material of GLB and GLBB. The magnitude of physics sought for this media is the amount of speed or speed [12]. Learning about motion material such as straight-motion changes irregularly requires learning aids to analyze more deeply about speed. The problem that often occurs in learning motion material is that this material is only conveyed in the form of theory, has not touched the psychomotor domain from theory to practice. The concept of initial velocity and final velocity on the Irregularly Changing Straight Motion concept will be challenging to understand when dealing with applicable problems [13]. Therefore we need learning aids to understand more integrally between theory and practice in analyzing speed by using a speed sensor (speed sensor). The speed sensor is used as an analysis of the real rate or travel time of Arduino-based objectsThe learning media developed using Arduino with electric motor strating to produce the amount of speed to get the category of service is used in learning [14]. Meanwhile, to produce variable speed by other means, speed sensors can be used to integrate with DC motors to produce wheel rotation and output RPM which is converted to units of meters per $(\mathrm{m} / \mathrm{sec})$. Therefore developed learning media using speed sensors to analyze the speed or speed with graph visualization. Speed Sensors' use in determining speed can help students calculate rate more accurately so that it has an impact on analytical skills for the better. It is hoped that with this media students will be better understanding the motion of GLB and the movement of GLBB so that it makes it easier to solve problems faced by students [15].

\section{METHOD}

This research is a Research and Development $(\mathrm{R} \& \mathrm{D})$ research, Research and Development methods are research methods used to produce certain products and test the effectiveness of these products [16]. The method used in this research is ADDIE research and development methods which include: (1) Analysis, (2) Design, (3) Development, (4) Implementation, (5) Evaluation [17]. Data collection methods using the method of observation, questionnaires and tests. The observation method is used as a basis for learning media and problem solving skills. The questionnaire method is used to assess the feasibility of 
instructional media by experts. The test method is used to obtain student ability data before and after learning.

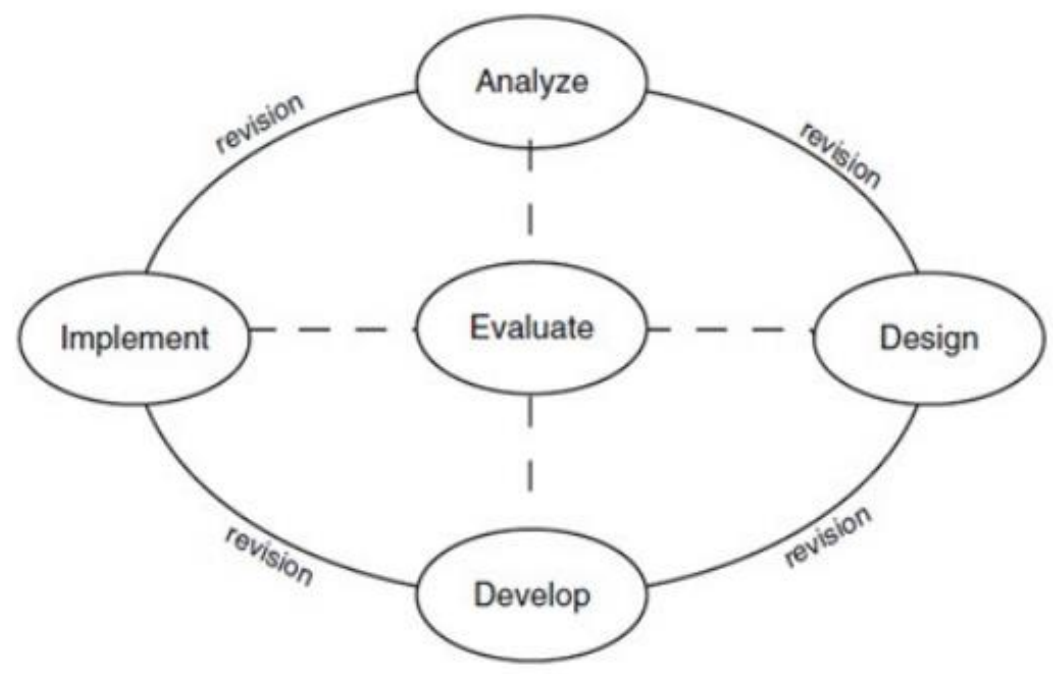

Fig1. ADDIE development flow chart

The results of the validation of instructional media by experts then analysis of questionnaires using choices with a Likert scale of 1-5, with very poor answer categories (P), less (L), enough (E), good (G) and very good (VG). The final results of the analysis of this questionnaire are stated with [18] as follows:

$$
\bar{x}=\frac{\Sigma f m}{\Sigma f a} \times 100 \%
$$

Information:

$\sum f m=$ Number of times the activity appeared

$\sum f a=$ Total frequency of all activities

$\bar{x} \quad=$ Average score

After the value obtained is then converted to a qualitative scale according to the table below.

Table 1. Reference on Changing Values to Scale Four

\begin{tabular}{cc}
\hline Score interval & Interpretion \\
\hline $0,00-1,69$ & Low \\
$1,70-3,50$ & Medium \\
$3,51-4,00$ & Good \\
\hline
\end{tabular}

\section{RESULTS AND DISCUSSIONS}

Research that has been done using the ADDIE model [17] with the following steps: (1) Analysis determines the right problems and solutions and determines student competence, (2) Design is carried out to determine specific competencies, methods, teaching materials and strategies used for the learning process, (3) Development is carried out to produce programs and teaching materials that will be used in the learning program, (4) Implementation, implement the learning program by applying the design or specifications of learning, (5) Evaluation, at this stage a Lecturer evaluates the learning program and evaluates the learning outcomes. The stages of instructional media development that have been carried out are as follows. 


\section{Analysis Phase}

At this stage the researchers conducted an analysis of what would be the basis for designing and developing products. Among them are analysis of student characteristics and analysis of media development. The following steps are outlined in the analysis:

\section{Analysis of Student Characteristics}

This stage is the initial stage for researchers to develop learning products that are developed. The safeguards were carried out on students of semester three for basic physics courses. Basic physics course is a basic course given in the early semester as an introduction to the field of production. This subject is also a prerequisite for meta lectures above. Although this course is side by side with basic physics practicum courses, it cannot yet accommodate theories and facilities for student development especially the ability to understand concepts. So much scope of material given in this eye causes not all material plans can be given to students, so that sometimes there is an unsynchronization between the theoretical concept material with practical material. This has an effect on students' subsequent understanding.

\section{Analysis of Media Development}

Learning that is out of sync between the theoretical material with practicum makes the understanding of students become partial. In addition, the basic physics practicums that have been carried out only revolve around certain materials and only revolve around the tools and materials available in the laboratory, but are not based on needs or learning plans. Practicum tools that are used are still conventional and manual, such as mechanical practicum in the motion of GLB-GLBB, still using a practicum motion kit with available tools are rarely calibrated and set regularly. The tools used are still manual, such as a timer measuring the object's travel time, these calculations sometimes provide inconsistent values in the initial calculation of the speed calculation. Distance is obtained from conventional calculations using a ruler for speed calculation. This affects the calculation of acceleration which will ultimately affect other calculations such as the calculation of motion on Newton's Laws I, II and Newton III's Law. Therefore it is necessary to make a tool that is more precise in its accuracy so that it will produce good accuracy values or minimize calculation errors and data calculations [19].

\section{Design Stage}

Based on the preliminary analysis stage of the learning media needed and in accordance with the problems faced, it is necessary to design learning media that can provide an accurate picture to represent GLB and GLBB material. The media is designed and developed in the form of Arduino-based GLBGLBB teaching media using Matlab as graphical data presentation software. The media design in the table above is arranged into the picture below.

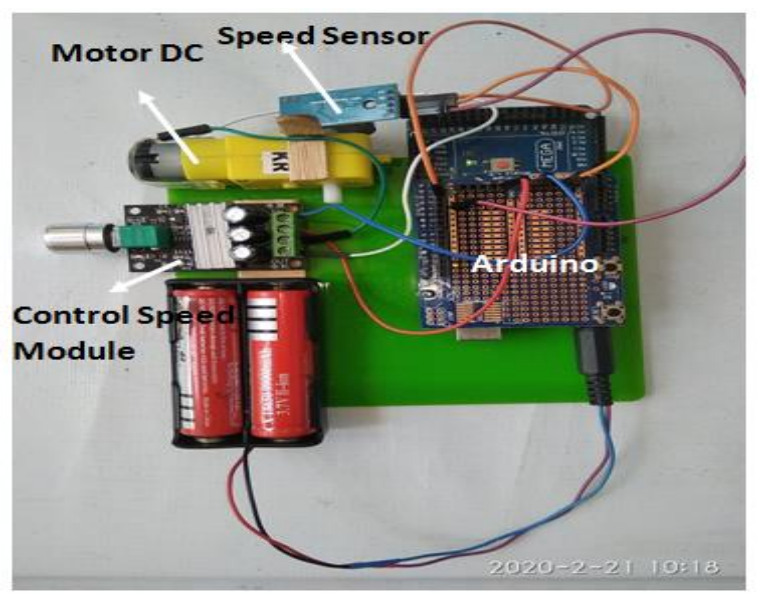

Fig 2. Series of Speed Measurement Tools Using Speed Sensors

Speed sensor as a speed control sensor with a DC motor will be controlled by the speed sensor module. This tool can be set for acceleration and deceleration. Display data obtained is the speed data derived from the conversion of RPM [20]. 
Speed calculation using the Speed sensor is more accurate and can save several stages, such as distance and time calculations. In contrast, the calculation of the speed using an infrared sensor can only help in more accurate time measurements [21]. The advantage of using this speed sensor can be applied to wheeled vehicle applications; speed sensors can be placed on the vehicle wheels to measure the rotating speed directly. The output of the Arduino programming results directly produces a rate in meters per second, as in Figure 3. The Arduino programmer output can show the phenomenon of acceleration and deceleration seen from the increase or decrease in speed, which can later be displayed in graphical form. Then an analysis process is carried out.

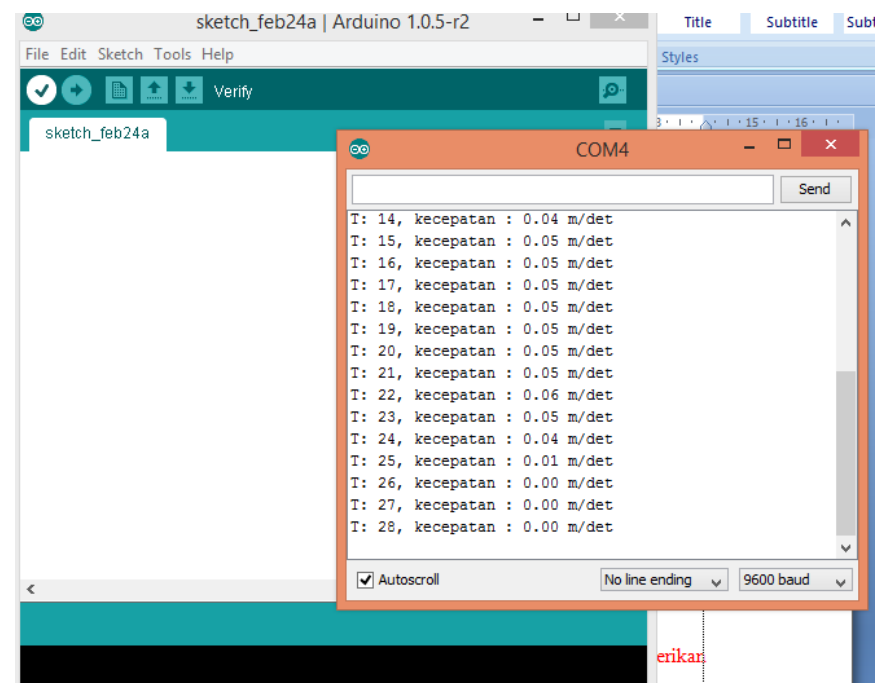

Fig 3. Serial Monitor Data Viewer Speed Measurement Tool

The program flow diagram illustrating the working tool system is shown in the Figure 4.

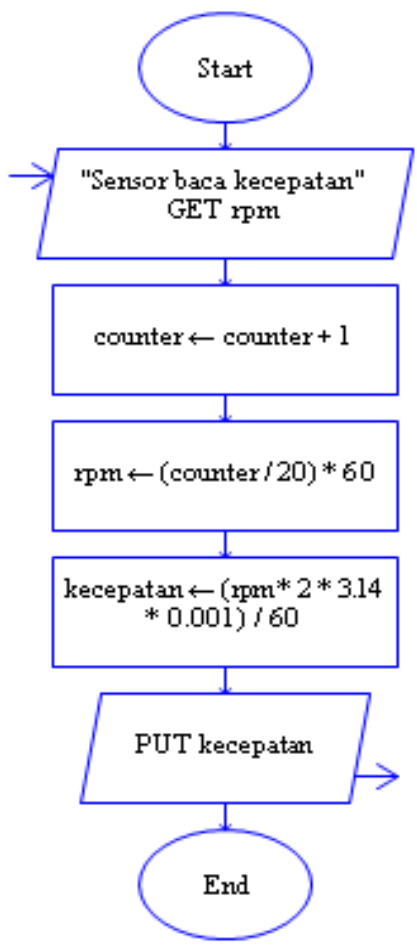

Fig 4. Flow Chart Program 
Development of Physics Teaching Media Using Speed Sensors as Speed Analysis... Umi Pratiwi, Siska Desy Fatmaryanti

Furthermore, the instructional media design above is used as Draft I to assess eligibility by experts. The results of the media expert validation test are presented in the table below.

Tebel 2. Recapitulation of Validation Value by Experts

\begin{tabular}{ccccc}
\hline Assessment Aspects & $\begin{array}{c}\text { Number of } \\
\text { Indicators }\end{array}$ & $\begin{array}{c}\text { Number of } \\
\text { Score }\end{array}$ & Average & Percentage \\
\hline Benefits Aspect & 7 & 27 & 3,8 & 14 \\
Presentation Aspects & 8 & 26 & 3,25 & 12,5 \\
$\begin{array}{c}\text { Physical Appearance } \\
\text { Aspects }\end{array}$ & 4 & 15 & 3,75 & 25 \\
\hline Amount & 19 & 68 & 10,8 & 51,5 \\
\hline
\end{tabular}

The recapitulation results of the experts' evaluation above show scores on three aspects of assessment, namely aspects of benefits, aspects of presentation, and aspects of physical appearance. The aspect of physical appearance gets the highest average score compared to other aspects, it's just that packaging needs to be interesting [22]. The results of the expert validation state that the GLB-GLBB learning media is good for improving problem solving skills as graph analysis.

The design of instructional media as Draft I also received advice and entered by experts as an evaluation material for Draft II, the advice / input of experts as follows:

1. Media visualization needs to be improved to make it more interesting,

2. Learning media as a speed gauge is a visualization of circular motion rather than GLBB motion, there needs to be a straight path,

3. The media is not to measure speed but speed, because it does not indicate direction,

4. The media should be made to measure speed.

After the Draft I was improved, it will be Draft II for testing the media in a small scope. Media testing was carried out in testing the output data with the speed variations in units of $\mathrm{m} / \mathrm{sec}$ until good calibration was produced. Then there will be a trial run on the learning class for fourth semester students.

\section{Development Phase}

At the Development stage, a learning media trial was conducted on the learning class of the GLB-GLBB material on the GLBB graph analysis of distance to time and GLBB for speed to time. Prior to the trial, a pre-test was carried out relating to initial understanding of GLB and GLBB and carried out a post-test after the demonstration and the use of media for graphical analysis. Data obtained as follows.

Table 3. Recapitulation Table of Pre-test and Post-test Problem Solving capabilities

\begin{tabular}{cccc}
\hline Indicator & Pre-test & Post-test & Average \\
\hline To identify problem in acase & 35.00 & 35.00 & 35.00 \\
Plan solution to problemfor a case & 36.25 & 36.25 & 36.25 \\
Solve the problemas planned & 41.25 & 43.75 & 42.5 \\
Check again the results obtained & 53.75 & 55.00 & 54.38 \\
\hline Average & 41.56 & 42.50 & \\
\hline
\end{tabular}

In the table above shows the score of problem solving ability, the fourth indicator gets the highest average score with an average of 54.38. While the lowest score on the first indicator is the ability to identify problems.

Problem-solving ability consisting of four indicators in Table 3 produces the highest score on the ability to re-examine the results obtained and the second-highest score to solve the problem at hand. This generally increases difficulty solving skills of $0.94 \%$. This is in line with research conducted [23], increasing problem-solving abilities of $15.15 \%$ with the replica props of the concept of straight motion, especially in the ability to solve problems. 


\section{CONCLUSION AND SUGGESTION}

Based on research that has been done in developing learning media GLB-GLBB using speed sensors to improve student problem solving it can be concluded as follows: development of GLB-GLBB learning media using speed sensors produces valid media to improve student problem solving, and development of learning media GLB-GLBB using a speed sensor produces an effective media to improve student problem solving by $2.2 \%$ of the initial ability, meaning that students are helped in analyzing graphs and motion concepts of GLB-GLBB with the variable distance to time as well as speed to time.

\section{REFERENCES}

[1] Novitasari, L., Agustina, P. A., Sukesti, R., Nazri, M. F., \& Handhika, J. (2017, August). Fisika, etnosains, dan kearifan lokal dalam pembelajaran sains. In Prosiding SNPF (Seminar Nasional Pendidikan Fisika) (pp. 81-88).

[2] Setiorini, I. (2014). Rancang Bangun Smart Timer Sebagai Alat Pengukur Waktu dan Kecepatan untuk Media Pembelajaran Gerak Lurus. Inovasi Fisika Indonesia, 3(02).

[3] Suseno, N., \& Riswanto, R. (2017). Program optimalisasi peran laboratorium fisika SMA di kota Metro, Lampung. Jurnal Pengabdian Pada Masyarakat, 2(2): 149-158.

[4] Yanti, D. E. B., Subiki, S., \& Yushardi, Y. (2017). Analisis Sarana Prasarana Laboratorium Fisika dan Intensitas Kegiatan Praktikum Fisika Dalam Mendukung Pelaksanaan Pembelajaran Fisika SMA Negeri di Kabupaten Jember. Jurnal Pembelajaran Fisika, 5(1): 41-46.

[5] Wijayanti, A. (2016). Implementasi model pembelajaran kooperatif tipe tgt sebagai upaya meningkatkan pemahaman konsep fisika dasar mahasiswa pendidikan IPA. Jurnal Pijar Mipa, 11(1).

[6] Kurniawati, I. D. (2018). Media pembelajaran berbasis multimedia interaktif untuk meningkatkan Pemahaman konsep mahasiswa. DoubleClick: Journal of Computer and Information Technology, 1(2): 68-75.

[7] Marhadini, S. A. K., Akhlis, I., \& Sumpono, I. (2017). Pengembangan media pembelajaran berbasis android pada materi gerak parabola untuk siswa sma. UPEJ Unnes Physics Education Journal, 6(3): 38-43.

[8] Sudjana, N., \& Arifin, D. (1995). Dasar-Dasar Pembelajaran. Bandung: Sinar Baru Algensindo.

[9] Király, A., \& Tél, T. (2017). Teaching Physics Innovatively. New Learning Environments and Methods in Physics Education.

[10] Qomariyah, N., \& Wirawan, R. (2018). Aplikasi Sensor Infrared dan Arduino Uno untuk Alat Peraga Sederhana Gerak Jatuh Bebas. Prosiding Konferensi Nasional Pengabdian Kepada Masyarakat dan Corporate Social Responsibility (PKM-CSR), 1: 652-659.

[11] Kadir, A. (2013). Panduan Praktis Mempelajari aplikasi mikrokontroler dan pemrogramannya menggunakan Arduino. Yogyakarta: Andi.

[12] Santoso, B., Putri, D. H., \& Medriati, R. (2020). Upaya Meningkatkan Motivasi Belajar Dan Kemampuan Pemecahan Masalah Siswa Melalui Model Problem Based Learning Berbantu Alat Peraga Konsep Gerak Lurus. Jurnal Kumparan Fisika, 3(1 April): 11-18.

[13] Hartini, S., Dewantara, D., \& Mahtari, S. (2018). Pengembangan alat peraga fisika energi melalui perkuliahan berbasis project based learning. Vidya Karya, 33(1): 42-50.

[14] Brox, P., Huertas-Sánchez, G., López-Angulo, A., Álvarez-Mora, M., \& Haya, I. (2016, June). Design of sensory systems using the platform Arduino by undergraduate Physics students. In 2016 Technologies Applied to Electronics Teaching (TAEE) (pp. 1-6). IEEE.

[15] Wijaya, C. A., Handhika, J., \& Kartikawati, S. (2017). Pengembangan media pembelajaran pengendali kecepatan dan soft starting motor listrik berbasis arduino pada mata kuliah penggunaan dan pengaturan motor. Jupiter (Jurnal Pendidikan Teknik Elektro), 2(2): 15-20.

[16] Sugiyono, S. (2015). Metode penelitian pendidikan pendekatan kuantitatif, dan R\&D. Alfabeta Bandung. 
[17] Pribadi, B. A. (2016). Desain dan Pengembangan Program Pelatihan Berbasis Kompetensi Implementasi Model ADDIE. Kencana.

[18] Sugiyono, P. (2015). Metode penelitian kombinasi (mixed methods). Bandung: Alfabeta.

[19] Muchlis, F., Sulisworo, D., \& Toifur, M. (2018). Pengembangan Alat Peraga Fisika Berbasis Internet of Things untuk Praktikum Hukum Newton II. Jurnal Pendidikan Fisika, 6(1): 13-20.

[20] Damayanti, R., Mayasari, T., \& Kurniadi, E. (2020, January). Profil Kemampuan Analisis Siswa dalam Menggunakan Media Pembelajaran Gerak Melingkar Berbasis Mikrokontroler ESP32 Dengan Tampilan Android. In Prosiding SNPF (Seminar Nasional Pendidikan Fisika).

[21] Subhan, K. M. J., \& Sucahyo, I. (2020). Pengembangan Alat Praktikum Hukum II Newton dengan Sensor Infrared untuk Melatihkan Keterampilan Proses Sains pada Siswa Kelas X. Inovasi Pendidikan Fisika, 9(2).

[22] Hendrawan, R., Budi, E., \& Bakri, F. (2019, December). Media Berbasis Arduino: Model Pengukuran Percepatan Gravitasi Bumi Dengan Prinsip Gerak Jatuh Bebas. In Prosiding Seminar Nasional Fisika (E-Journal) (Vol. 8, pp. SNF2019-PE).

[23] Santosa, E. S. B., \& Waluyanti, S. (2019, November). Teaching Microcontrollers using Arduino Nano Based Quadcopter. In Journal of Physics: Conference Series (Vol. 1413, No. 1, p. 012003). IOP Publishing. 